\title{
Latin-American European citizens: Some consequences of the autonomy of the member States of the European Union in nationality matters
}

Citation for published version (APA):

de Groot, G. R. (2002). Latin-American European citizens: Some consequences of the autonomy of the member States of the European Union in nationality matters. Maastricht Journal of European and Comparative Law, 115-120. https://doi.org/10.1177/1023263X0200900201

Document status and date:

Published: 01/01/2002

DOI:

10.1177/1023263X0200900201

Document Version:

Publisher's PDF, also known as Version of record

Please check the document version of this publication:

- A submitted manuscript is the version of the article upon submission and before peer-review. There can be important differences between the submitted version and the official published version of record.

People interested in the research are advised to contact the author for the final version of the publication, or visit the DOI to the publisher's website.

- The final author version and the galley proof are versions of the publication after peer review.

- The final published version features the final layout of the paper including the volume, issue and page numbers.

Link to publication

\footnotetext{
General rights rights.

- You may freely distribute the URL identifying the publication in the public portal. please follow below link for the End User Agreement:

www.umlib.nl/taverne-license

Take down policy

If you believe that this document breaches copyright please contact us at:

repository@maastrichtuniversity.nl

providing details and we will investigate your claim.
}

Copyright and moral rights for the publications made accessible in the public portal are retained by the authors and/or other copyright owners and it is a condition of accessing publications that users recognise and abide by the legal requirements associated with these

- Users may download and print one copy of any publication from the public portal for the purpose of private study or research.

- You may not further distribute the material or use it for any profit-making activity or commercial gain

If the publication is distributed under the terms of Article $25 \mathrm{fa}$ of the Dutch Copyright Act, indicated by the "Taverne" license above, 
Editorial

\section{Latin-American European citizens: Some consequences of the autonomy of the Member States of the European Union in nationality matters}

Art. 17(1) EC Treaty (as amended by the Treaty on the European Union) provides:

Citizenship of the union is hereby established.

Every person holding the nationality of a Member State shall be a citizen of the Union.

Since the Treaty of Amsterdam Art. 17 continues:

Citizenship of the Union shall complement and not replace national citizenship.

Of course, one has to raise the question, who determines which persons are entitled to the nationality of a member state. Should the member state involved decide or should it fall within the competence of the European Union, because the nationals of the member states are consequently entitled to European citizenship?

An answer is given in a special Declaration (no 2) on nationality of a Member State, which has been added to the Treaty of Maastricht. The declaration provides:

The Conference declares that, wherever in the Treaty establishing the European Community reference is made to nationals of the Member States, the question whether an individual possesses the nationality of a Member State shall be settled solely by reference to the national law of the Member State concerned. Member States may declare, for information, who are to be considered their nationals for Community purposes by way of a declaration lodged with the Presidency and may amend any such declaration when necessary. 
Every member state seems to be completely autonomous with regard to the regulation of the nationality of its own country. This autonomy was in principle underscored by the European Court of Justice in Micheletti. ${ }^{1}$ The Court accepted the Italian interpretation of the Italian-Argentinean treaty on double nationality, ${ }^{2}$ because the right of interpretation was a domestic matter and did not violate international or Community law. The member state's autonomy was recently emphasized again in re Kaur, ${ }^{3}$ in which the ECJ affirmed the United Kingdom's right to exclude inter alia British Overseas Citizens from the scope of British nationals for Community purposes (and therefore from European citizenship) in a unilateral declaration. ${ }^{4}$ The British declaration involved could be seen as a declaration in the sense of the above-cited Declaration on nationality of a Member State as attached to the Maastricht Treaty.

Apart from the United Kingdom, only one other member state has made a declaration on the definition of nationals for Community purposes. As far back as 1957, Germany declared that not only Germans in the sense of the German nationality statute (the modified Reichs- und Staatsangehörigkeitsgesetz 1913, which already included all nationals of the Democratic Republic of Germany) must be regarded as Germans for European Community purposes, but also Germans in the sense of Art. 116 of the Constitution (Grundgesetz), which includes ethnic Germans in Eastern Europe, for example the so-called Wolga-Germans, if they come to Germany as refugees ('Vertriebene'). ${ }^{5}$ However, since 1 January 2000, this German declaration no longer has practical relevance, because since then everyone who is recognized as a German according to Art. 116 of the German Constitution simultaneously acquires ex lege German nationality in the sense of the reformed German nationality statute. ${ }^{6}$

It is remarkable, that Spain did not make a declaration to explain precisely who Spanish citizens for Community purposes are. Nor does the Accession Treaty of Spain to the EC contain any provision, which could aid with the determination of Spanish nationals,

1. Case C-369/90 Michelleti [1992] ECR 1-4239-4263. On this judgment, see Gerard-René de Groot, 'Migrantenrecht', 7 Katern voor de rechtspraktijk (1992), 105-110 and Hans-Ulrich Jessurun d'Oliveira, 30 Common Market Low Review (1993), 623-637.

2. Concluded in Buenos Aires on 29 October 1971; in Italy approved by Legge of 18 May 1973, no. 282, G.U. 24 June 1973, no. 152.

3. Case C-192/99 Kaur [2001] ECR I-1237. On that judgment, see Hans Ulrich Jessurun d'Oliveira, 5 Jurisprudentie Vreemdelingenrecht (2001), 469-477 and H. Staples, 'Wie is burger van de Unie?', Nederlands tijdschrift voor Europees Recht (2001), 109-112.

4. A modified declaration will be necessary after the British Overseas Territories Act 2002 comes in force. This Act received Royal consent on 26 February 2002.

5. See Treaties establishing the European Communities, Office for Official Publications of the European Communities 1978, 573. Compare Albert Bleckmann, 'German nationality within the meaning of the EEC Treaty', Common Market Law Review (1978), 435-446. In addition, see Hans Ulich Jessurun d'Oliveira, 'Nationality and the European Union after Amsterdam', in: David O'Keeffe and Patrick Twomey, Legal issues of the Amsterdam Treaty, (Oxford University Press, 1999), 400.

6. Par. 7 of the German Nationality Act, as modified by Act of 15 July 1999, Bundesgesetzblatt 1999 I 1618. Also sec the transitory provision of Par. 40a. 
who are entitled to the benefits of Community law. Spain has concluded several treaties on multiple citizenship with Latin-American countries. ${ }^{7}$ Spaniards who acquire the nationality of those Latin American countries do not lose Spanish nationality, whereas the citizens of those Latin American countries can acquire Spanish citizenship without losing the Latin American nationality involved. These 'Tratados de doble nacionalidad" constituted a problem that obviously was discussed during the negotiations regarding the accession of Spain to the Community. This fact I conclude from a publication of Elisa Perez Vera from $1981 .^{8}$ She writes, that these treaties constitute an aspect of Spanish nationality law which seems to cause reservations by certain Community lawyers, who plead for its modification. ${ }^{9}$

The goal of Elisa Perez Vera's publication was to convince lawyers, that the Spanish system of double citizenship did not constitute a danger for other EC member states, because of the particular character of double nationality according the Treaties on double nationality. If a Spaniard acquires the nationality of a Latin American country, which has concluded a treaty on double nationality with Spain, he will not lose Spanish citizenship, but during the time he resides in a country other than Spain he does not enjoy any right attached to Spanish citizenship: ${ }^{10}$ he is for instance not entitled to a Spanish passport, which would allow him to identify himself as a European citizen. His Spanish nationality is dormant ('en hibernacion'; in hibernation) until he settles in Spain again. Upon doing so, his Spanish nationality revives, including all the rights attached to this nationality (including the rights which Spaniards possess as European citizens). The same rules apply to the children and other descendants of persons who have such a dormant Spanish nationality. They are therefore not European citizens: a clear example of the old principle 'nemo plus ituris transferre potest quem ipse habet'. Obviously, the Spanish government convinced Brussels with similar arguments, given the fact that Spain did not make an explanatory declaration on Spanish nationality excluding those 'dormant' Spaniards with a Latin American nationality from the benefits of the EC Treaty.

7. Argentina, Bolivia, Chile, Costa Rica, Dominican Republic, Ecuador, Guatemala, Honduras, Columbia, Nicaragua, Paraguay and Peru. For further information see Juan Aznar Sanchez, La doble nacionalidad (docirina, legislación, jurisprudencia), (Madrid Marcial Pons, 1977).

8. Perez Vera, 'El sistema español de doble nacionalidad ante la futura adhesion de Espafia a las Communidades Europeas' ('The Spanish system of double citizenship in perspective of the future accession to the European Communities'; English translation GRdG), Revista de instituciones europeas (1981), 685-703.

9. Perez Vera, Revista de institutiones europeas, 685: 'es ... un aspecto del Derecho español de nacionalidad que parece despertar serias reservas en ciertos juristas comunitarios que abogarian por su modificacion'.

10. The same principle applies if a national of the Latin American countries involved acquires Spanish nationality by naturalization. See for example Art. 1 (2) of the Spanish-Argentinean treaty of 14 April 1969: 'Las personas que se acojan a las disposiciones del presente Convenio quedarán sometidas a la legislación del país que ha otorgado la nueva nacionalidad y en ningún caso a la legislación de ambas Partes contratantes simultáneamente'. 
From this perspective it is understandable that Spain was not amused by the Italian government's opinion that Mario Vicente Micheletti, born in Argentina as the son of a naturalized Argentinean/Italian father, had to be treated as Italian for Community purposes despite the content of an Italian/Argentinean treaty on double nationality, which was in fact a copy of the Spanish/Argentinean treaty on double nationality. Under similar circumstances, based on their treaty with Argentina, Spain would conclude that a child of a naturalized Argentinean/Spaniard would not qualify as Spanish for Community purposes. Nevertheless, Spain must accept the Italian interpretation of the Italian-Argentinean Treaty. It is therefore - to put it politely - extremely remarkable, that it can nevertheless be observed that the Spanish courts did not always follow the Micheletti judgment. The Supreme Court of Spain (the Tribunal Supremo) refused, in a decision of 27 November $1996,{ }^{11}$ to grant a residence card for European citizens ('tarjeta de residente comunitario') to a double Argentinean/Italian citizen because of art. 9.9 and 9.10 of the Spanish civil code. ${ }^{12}$ It did not mention the ruling of the European Court of Justice in its Micheletti judgment. ${ }^{13}$ I tend to conclude, that this decision of the Tribunal Supremo was an obvious violation of Community law. In a later decision, however, of 11 November 1997, the Tribunal Supremo did follow the ruling of the ECJ. ${ }^{14}$

Even more interesting is the fact that - obviously inter alia as a consequence of the ECJ's decision in Micheletti - Spain is amending its treaties on double nationality with various Latin-American states.

Two types of amendments can be observed. An example of the first type of amendment to the treaties on double nationality is the protocol concluded in Madrid on 23 October 1997 amending the treaty with Costa Rica, ${ }^{15}$ which came into force on 1 December

11. RJ 1996/8171; see on this decision Gerard-René de Groot, Negeert Spanje de Micheletti-beslissing van het Europese Hof van Justitie?', 13 Migrantenrecht (1998), 117, 118.

12. The same articles were at the heart of the discussion in the Micheletti case. At first sight it is astonishing that Spain wanted to use Art. 9 (9) Civil code. This article starts with the words 'For the legal consequences of this chapter ...' ('A los efectos de este capitulo ...'). The chapter involved deals with the conflict rules of private international law ('Capitulo IV: Normas de derecho internacional privado'). One would expect, that this provision would not apply at all to the problems in the Micheletti case, but exclusively in conflict of laws matters. Did the Spanish authorities make a mistake? For non-Spanish lawyers it does not make sense to defend an opinion on this point. It is a Spanish matter to decide in which cases the content of the rule of Art. 9 (9) Civil code has to be applied in despite of the text of the article, perhaps 'per analogiam'.

13. Jessurun d'Oliveira, 'Nationality and the European Union after Amsterdam', in David O'Keeffe and Patrick Twomey (eds.), Legal Issues of the Amsierdam Treaty, (Hart Publishing, 1999), which is according to the opinion of the ECJ obviously not a rule of customary international law.

14. Decision of 11 November 1997, Jurisdiccion Contencioso Administrativa, Seccion 6.

15. BOE Nr. 271 of 12 November 1998. 
1998. ${ }^{16}$ The Protocol makes it possible for Spanish-Costa Ricans to renounce the application of the treaty on double nationality concluded between Spain and Costa Rica. The consequence of such a renunciation is not the loss of Spanish nationality, but on the contrary, the complete revival of Spanish nationality, including the entitlement to a Spanish passport, which is necessary for the identification as a European citizen. ${ }^{17}$ This is caused by the fact that the Spanish Constitution and (since 1954) the nationality provisions of the Spanish civil code (in particular Art. 23) provide, that Spanish nationality is not lost in case of voluntary acquisition of - inter alia - the nationality of a Latin American country. ${ }^{18}$

Another type of amendment to the treaties involved is illustrated by the additional protocol concluded in Asunción on 26 June 1999 with Paraguay ${ }^{19}$ (in force on 1 March 2001). ${ }^{20}$ According to these protocols, double nationals to whom the treaty applies simply get the right to a Spanish passport. ${ }^{21}$ Under EC law they can identify themselves with this passport as European citizens. ${ }^{22}$

In the meantime seven protocols have been concluded: with Bolivia, Costa Rica and Nicaragua of the first type (denunciation of the application of the treaty is possible) and with Argentina, Guatemala, Paraguay and Peru of the second type (entitlement to passport). Obviously, Spain wants to amend other treaties on double nationality (with Chile, Dominican Republic, Ecuador, Honduras and Colombia) in a similar manner. If this happens the access to European citizenship will become much easier for a large number of Latin Americans of Spanish origin.

The most sensational protocol was concluded on 6 March 2001 with Argentina. A protocol of the second type was concluded and a provision that the protocol would come into force - provisionally - on the same day was added. Given the extremely bad economic situation in Argentina, it is not surprising that large numbers of people used

16. See also the additional protocol of 12 Novermber 1997 amending the Treaty with Nicaragua (in force on 18 March 1999; BOE Nr. 158 of 29 January 1999); the additional protocol of 18 October 1997 amending the treaty with Bolivia (in force on 1 February 2002; BOE Nr. 46 of 22 Fcbruary 2002).

17. I conclude this from an atticle by Aurelia Alvarez Rodriguez, "Modificacion del Convenio de doble nacionalidad entre España y Nicaragua', http://www.reicaz.es/extranjeria/revista/001/01_003.htm (visited on 28 August 2000 and regrettably no longer available in May 2002).

18. See Gerard-René de Groot, Staatsangehörigkeitsrecht im Wandel, (Heymanns Verlag, 1989) 187-189.

19. BOE Nr. 89 of 13 April 2001.

20. See also the second additional protocol of 19 November 1999 amending the treaty with Guatemala (BOE Nr. 88 of 12 April 2001 ); the additional protocol of 8 November 2000 amending the Treaty with Peru (in force on 1 December 2001) and - last but certainly not least - the additional protocol of 6 March $200 \mathrm{l}$ amending the Treaty with Argentina (BOE Nr. 88 of 12 April 2001).

21. Art. 3 Protocol with Peru: 'Las personas beneficiarias por el Convenio tienen el derecho de obtener $y$ renovar sus pasaportes y demas documentos de identificación en cualquiera de los dos países o en ambos al mismo tiempo.'

22. See Art. 2 (1) and 6 (a). Directive 73/148 (establishment and services) and Art. 3 (1) and 4 (3) (a) Directive $68 / 360$ (workers). 
this newly created possibility to apply for Spanish passports. In the Spanish consulate in Buenos Aires alone 25,400 Argentinean citizens received a Spanish passport in 2001. ${ }^{23}$

There is no reason to be happy with these developments. Although, one has to realize that it is extremely difficult to blame Spain for this generous grant of Spanish passports to Latin Americans considering that Spain had to accept the free movement rights of Micheletti due to the generous interpretation by the Italian government of the scope of application of the Italian/Argentinean treaty.

In this context a very recent development must also be mentioned. On 23 May 2002, the Spanish 'Congreso de los Diputados' accepted a bill amending the nationality provisions of the Spanish civil code. ${ }^{24}$ Access to Spanish nationality for children and grandchildren of Spanish emigrants will be made much easier. ${ }^{25}$ Children of a father or mother, who originally possessed Spanish nationality and was born in Spain, can acquire Spanish nationality by lodging a declaration of option (Art. 20 (1) (b)). The declaration can also be made outside of Spain. The right of option is not limited in respect of the age of the person involved. The grandchildren of persons who originally possessed Spanish nationality will be able to acquire Spanish nationality by naturalization after a residence period of one year (Art. 22 (2) (f)). In respect of these modifications one also has to realize that Italy facilitates access to Italian nationality for the children and grandchildren of Italian emigrants in a similar way. ${ }^{26}$

For the other member states of the European Union it is time to reconsider the desirability of quasi-absolute autonomy of member states in nationality matters. It may be desirable to exercise influence over the access of third country nationals to European citizenship via the nationality of some member states. It is desirable to have the European Commission consider undertaking action in this respect.

Gerard-René de Groot

23. El Pais 19 January 2002. The same article mentions that 21.511 passports were granted in the year 2000 and 17,167 in 1999. Data on the four other Spanish consulates in Argentina (in Rosario, Córdoba, Mendoza and Bahla Blanca) were not mentioned.

24. El Pais 18 May 2002; La Vanguardia Digital 24 May 2002.

25. See Boletín Oficial de las Cortes Generales, Congreso de los Diputados, 16 May 2002, Nr. 241-1.

26. See Art. 4 and 9 Legge sulla cittadinanza italiana of 5 February 1992 and Art. I of the Act Nr. 379 of 14 December 2000, G.U. Nr. 295 of 19 December 2000. 